\title{
焼結ステンレス鋼切削における工具摩耗
}

\author{
和田 任弘 \\ 奈良工業高等専門学校機械工学科, 个 639-1080 大和郡山市矢田町 22.
}

\section{Tool Wear in Cutting of Sintered Stainless Steel}

\author{
Tadahiro Wada \\ Department of Mechanical Engineering, Nara National College of Technology, 22 Yata-cho, Yamatokoriyama 639-1080.
}

Received March 9, 2001

\section{SYNOPSIS}

The tool life in turning of the sintered steels becomes shorter than that in turning of the melted steels such as carbon steels. In order to clarify the effective tool materials for the turning of the sintered stainless steel, the tool wear is experimentally investigated. The sintered stainless steel was turned with the various tool materials at the cutting speed from $1.67 \mathrm{~m} / \mathrm{s}$ to $5 \mathrm{~m} / \mathrm{s}$. The main results obtained are as follows: (1) In the conventional tool materials, the cemented carbide tool (coated by TiVN PVD) is the most effective tool material for the turning of the sintered stainless steel. (2) In the three kinds of CBN tools, the tool wear of the CBN tool with TiN binder increases slower than those of the $\mathrm{CBN}$ tool with $\mathrm{Al}_{2} \mathrm{O}_{3}$, TiC binder. (3) The $\mathrm{CBN}$ tool with TiN binder gets a better surface finish than the $\mathrm{CBN}$ tool with $\mathrm{Al}_{2} \mathrm{O}_{3}$ binder. Therefore, the $\mathrm{CBN}$ tool with TiN binder is the most effective tool material for the turning of the sintered stainless steel.

\section{KEYWORDS}

turning, sintered stainless steel, tool wear, surface roughness, SUS316L

\section{1 緒 言}

耐食性を要求される㟐結部品には，焼結ステンレス鋼が使

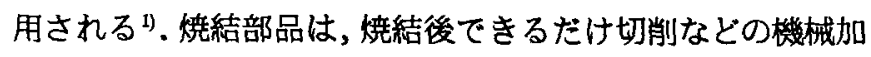
エをしなくてすむように設計するのが望ましいが2), 寸法精度 が要求される場合には切削が行われる.焼結部品の切削にお いては, 烧結材料は気孔を含有し, 熱伝導率が低いなどの理 由で被削性はあまり良くないとされている37.さらに, 焼結部 品は多量に生産されるので耐摩耗性に優れ，しかも能率を高 めるために高速度切削が可能な工具材を選定する必要がある. これには，耐熱・耐摩耗性に優れたセラミックスやc-BNが有 効な工具材と考えられる.しかし，焼結ステンレス鋼切削に おけるセラミックスやc-BNの工具摩耗を調べた研究は見あた らない，そこで，他の文献を参考にすると，娔結鋼切削にお いては，TiC含有量の多いアルミナ系セラミックスが有効で あるむとしている.しかし，溶製材としてのステンレス鋼切削 においては,アルミナセラミックスはNiやTiとも反応を起こ して異常摩耗を生じるので,これらを多く含有する材料の切
削には注意が必要である5)との報告もある，また，c-BNで焼 結ステンレス鋼を切削する場合, c-BNの結合材は工具摩耗に 大きな影響を与える 合材を選定する必要がある。一方，横穴など成形困難な場合 にも切削が行われる。この場合, 工具材には耐欠損性・耐摩 耗性に優れていることが要求される.これには, 耐欠損性に 優れた超硬合金を母材とし耐摩耗性に優れたセラミックスを コーティングしたコーテッド超硬合金が有効な工具材と考え られる.しかし，焼結ステンレス鋼切削におけるコーテッド 超硬合金の工具摩耗を調べた研究も見あたらない。

そこで本研究では，焼結ステンレス鋼(SUS316Lに相当)切 削時に適した工具材を明らかにするために，超硬合金，コー テッド超硬合金, セラミックス,およびc-BNの工具摩耗を調 ベた.

\section{2 実験方法}

被削材として使用した焼結ステンレス鋼の化学成分および 
機械的性質を Table 1 に示す. 被削材焼結ステンレス鋼の引張 り強さは 200〜350 MPa, 硬度はHB94である. Fig.1に, 焼結 ステンレス鋼の組織写真を示す．黒い部分が気孔である.

使用工具材は, 超硬合金 P10, K10 種, Table 2 に示すコー テッド超硬合金, セラミックスおよびc-BNである.コーテッ ド超硬合金は, 超硬合金 K10種を母材に, TiN, TiVN, TiAlNを PVD 被覆したもの，および TiN-TiCN- $\mathrm{Al}_{2} \mathrm{O}_{3}-\mathrm{TiN}$ を多層 CVD 被覆したものである. セラミックスは, $\mathrm{Al}_{2} \mathrm{O}_{3}$ セラミックス， $\mathrm{Al}_{2} \mathrm{O}_{3}$ と $\mathrm{TiC}$ 含有量の異なる $\mathrm{Al}_{2} \mathrm{O}_{3}-\mathrm{TiC}$ セラミックスおよび $\mathrm{Si}_{3} \mathrm{~N}_{4}$ セラミックスを用いた. c-BNについては, $\mathrm{TiC}, \mathrm{Al}_{2} \mathrm{O}_{3}$, TiN 結合材の c-BN を用いた，なお，c-BN 含有率は，いずれ の c-BN も 60〜 65 vol.\% である.

$\square 25 \times 25$ バイトホルダに，TNGA160408, TNMA160408，あ るいはTNGN160408型チップを取付け使用した.この場合の 工具形状は, いずれのチップも $-6^{\circ},-6^{\circ}, 6^{\circ}, 6^{\circ}, 30^{\circ}, 0^{\circ}$, $0.8 \mathrm{~mm}$ となる. また, いずれのセラミックス, c-BNの工具切 れ刃には $\left(0.1 \sim 0.2 \mathrm{~mm} \times 25^{\circ}\right)$ のチャンファホーニングが施され ている.

使用旋盤は，無段変速装置付き昌運工作所製 ST $5 \times 1000$ 型 高速精密旋盤 $(7.5 / 11 \mathrm{~kW}, 8 〜 2500 \mathrm{rpm})$ である.

Table 3に示す切削条件で焼結ステンレス鋼の外周旋削を行 い, 工具摩耗, 仕上げ面粗さなどを調べた. 仕上げ面粗さの 測定には, 東京精密社製サーフコム $1800 \mathrm{~A}$ 型触針式表面粗さ 測定器を用い, 送り方向の仕上げ面のプロフィールを記録し た.

Table 1 Chemical compositions and mechanical properties.

\begin{tabular}{ccccccc}
\hline $\mathrm{Cr}$ & $\mathrm{Ni}$ & $\mathrm{Mo}$ & $\mathrm{Si}$ & $\mathrm{Mn}$ & $\mathrm{C}$ & $\mathrm{Fe}$ \\
\hline $16 \sim 18$ & $12 \sim 15$ & $2 \sim 3$ & $<1.5$ & $<2$ & $<0.03$ & Bal. \\
\hline $\begin{array}{l}\text { Mechanical } \\
\text { properties }\end{array}$ & Tensile strength & $200 \sim 350 \mathrm{MPa}$ \\
\cline { 2 - 6 } & Brinell hardness & \multicolumn{3}{c}{ HB94 } & \\
\hline
\end{tabular}

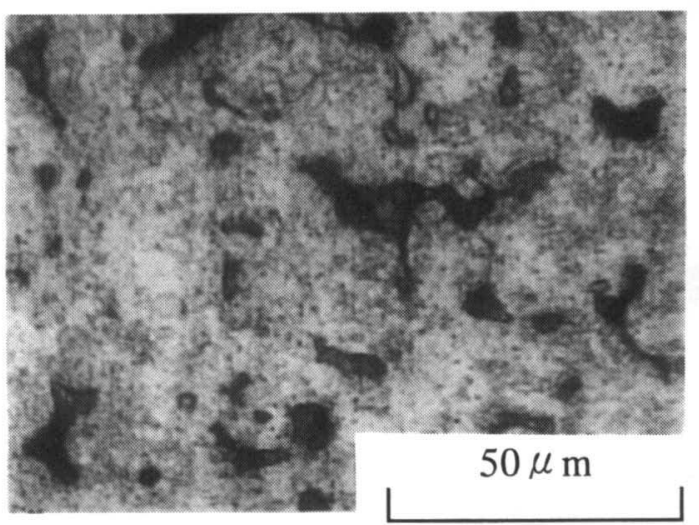

Fig.1 Microstructure of sintered stainless steel.

\section{3 実験結果およひ考察}

3.1 切りくず形状

切りくず形状は切りくずの処理性に直接影響する ${ }^{9}$. そこ で，焼結ステンレス鋼旋削時に得られた切りくずを調べた. Fig.2(a)に, 焼結ステンレス鋼を TiNコーテッド超硬合金工具 で旋削した場合に得られた切りくずを示す. 切削速度は $5.0 \mathrm{~m} / \mathrm{s}$ である.ここでは示していないが, 引張り強さ $600 \mathrm{MPa}$ の焼 結鋼を切削すると不連続形切りくずが生成された ${ }^{4}$. これは, 被削材の伸びが小さいため被削材内部に存在する気孔の部分 で切削が不連続になり，切りくずが折れやすくなるためであ る.しかし, Fig.1に示したように焼結ステンレス鋼内部にも 気孔が存在するが, 連続形切りくずが生成される.これには, 次の理由が考えられる. Fig.2(b)に Fig.2(a)で示した切りくず の断面を示す. Fig.2(b) 中に示す A, B 部いずれの部分も大き な気孔は存在せず, 気孔が押しつぶされ線状となっている. このことから, 焼結ステンレス鋼の伸びが大きいため, 気孔 が押しつぶされることにより連続形切りくずが生成されたと 考えられる.

3.2 コーテッド超硬合金工具

3.2.1 工具の摩耗状態

焼結ステンレス鋼を各種工具材で旋削し，工具の摩耗状態 を調べた. その結果を, Fig.3に示す. 切削速度は, $5.0 \mathrm{~m} / \mathrm{s}$ の 場合である. (a)に示す超硬合金 K10種工具の場合, コーナ部

Table 2 Tool materials.

\begin{tabular}{|c|c|}
\hline Tool & Tool material \\
\hline Coated A & $\mathrm{K} 10\left(\mathrm{TiN}^{*}\right)$ \\
\hline Coated B & $\mathrm{K} 10\left(\mathrm{TiVN}^{*}\right)$ \\
\hline Coated C & K10 ( TiAlN*) \\
\hline Coated D & $\begin{array}{l}\mathrm{K} 10 \\
\left(\mathrm{TiN}-\mathrm{TiCN}-\mathrm{Al}_{2} \mathrm{O}_{3}-\mathrm{TiN}^{* *}\right)\end{array}$ \\
\hline Ceramics W & $\mathrm{Al}_{2} \mathrm{O}_{3}(100 \%)$ \\
\hline Ceramics B & $\mathrm{Al}_{2} \mathrm{O}_{3}(70 \%)-\mathrm{TiC}(30 \%)$ \\
\hline Ceramics $\mathrm{T}$ & $\mathrm{Al}_{2} \mathrm{O}_{3}(30 \%)-\mathrm{TiC}(70 \%)$ \\
\hline Ceramics S & $\mathrm{Si}_{3} \mathrm{~N}_{4}$ \\
\hline CBN C & c-BN ( TiC binder) \\
\hline CBN D & $\mathrm{c}-\mathrm{BN}\left(\mathrm{Al}_{2} \mathrm{O}_{3}\right.$ binder $)$ \\
\hline CBN N & c-BN ( TiN binder) \\
\hline
\end{tabular}

Table 3 Cutting conditions.

\begin{tabular}{ll}
\hline Cutting speed & $\mathrm{V}=1.67,5.0 \mathrm{~m} / \mathrm{s}$ \\
Feed rate & $\mathrm{S}=0.2 \mathrm{~mm} / \mathrm{rev}$ \\
Depth of cut & $\mathrm{a}=0.1 \mathrm{~mm}$ \\
Cutting method & Dry \\
\hline
\end{tabular}


(a)

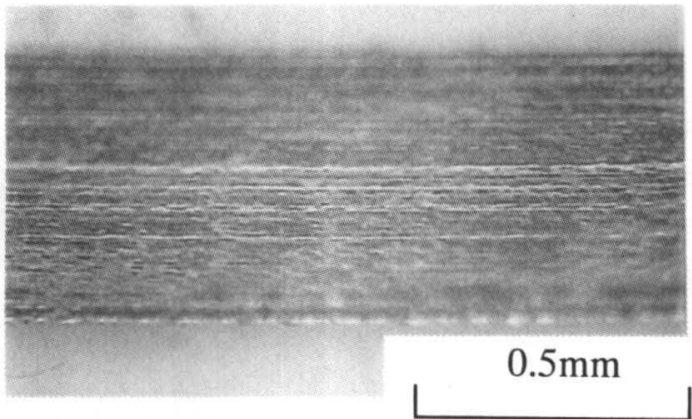

$(\mathrm{V}=5.0 \mathrm{~m} / \mathrm{s}, \mathrm{S}=0.2 \mathrm{~mm} / \mathrm{rev}$, $\mathrm{a}=0.1 \mathrm{~mm}$, Coated B)

(b)
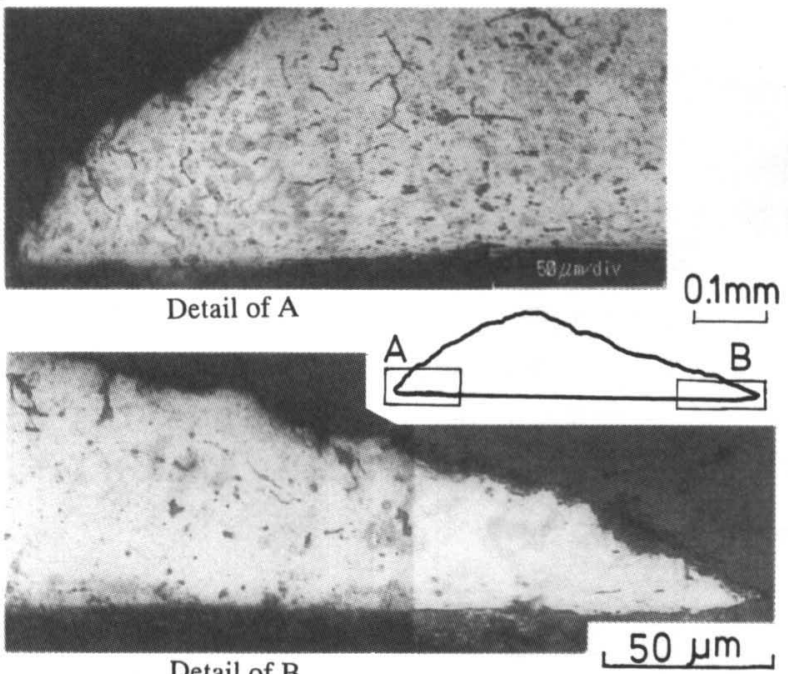

Detail of B

Fig.2 Chip obtained in turning of sintered stainless steel. (a) Chip configuration. (b) Cross section of chip shown in Fig.(a).

の逃げ面が三角形状に大きく摩耗している.さらに, 刃先後 退量もかなり大きい. (b), (c)にそれぞれ示すコーテッド超硬 合金工具 $\mathrm{A}, \mathrm{B}$ の場合, コーティング層の顕著な剥離は見られ ない.これに対し, (d)に示すコーテッド超硬合金工具Dの場 合,コーナ付近のすくい面にコーティンク層の剥離が見られ， さらに逃げ面に凝着物が見られる。

\section{2 .2 工具の摩耗進行}

焼結ステンレス鋼を 2 種の超硬合金工具で切削し，工具の 摩耗進行を調ぺた. Fig.4に，その結果を示す. 切削速度は $1.67 \mathrm{~m} / \mathrm{s}$ の場合で，超硬合金 $\mathrm{K} 10$ 種工具については切削速度 $5.0 \mathrm{~m} / \mathrm{s}$ の場合も示す. 切削速度 $1.67 \mathrm{~m} / \mathrm{s}$ の場合，超硬合金 $\mathrm{K} 10$ 種工具の摩耗進行は遅く, 40 分切削後の逃げ面摩耗幅の最大 值は $0.2 \mathrm{~mm}$ 程度である. 超硬合金 $\mathrm{K} 10$ 種工具の摩耗進行が遅 くなるのは, 超硬合金 $\mathrm{K} 10$ 種の熱伝導率 $(79 \mathrm{~W} / \mathrm{m} \cdot \mathrm{K})$ が超硬合 金P10 $(29 \mathrm{~W} / \mathrm{m} \cdot \mathrm{K})$ に比べ大きい ${ }^{19}$ ので，切削温度が上昇しに くくなり工具の摩耗進行が遅くなったと考えられる. そこで, 超硬合金 K10種工具については，さらに切削速度を $5.0 \mathrm{~m} / \mathrm{s}$ に 大きくして焼結ステンレス鋼の切削を行った。その結果，超

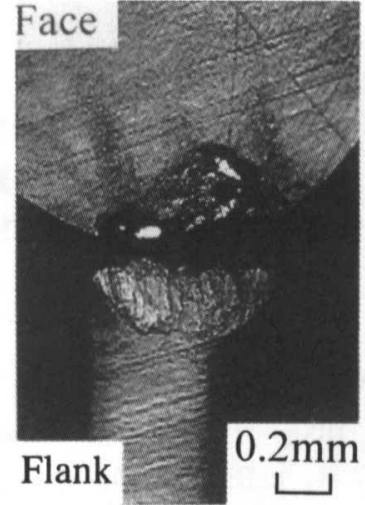

(a) $\mathrm{K} 10(\mathrm{~L}=0.2 \mathrm{~km})$

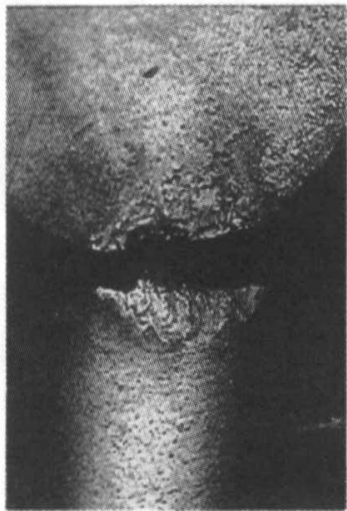

(c) Coated B

( $\mathrm{L}=2.0 \mathrm{~km}$ )

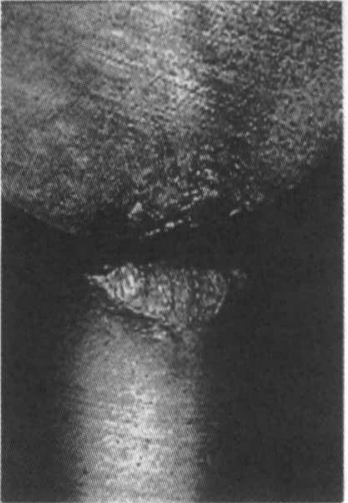

(b) Coated A

$(\mathrm{L}=1.6 \mathrm{~km})$

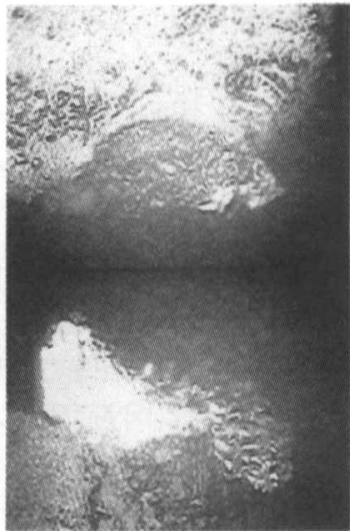

(d) Coated D

( $\mathrm{L}=0.8 \mathrm{~km}$ )

Fig.3 Tool wear.

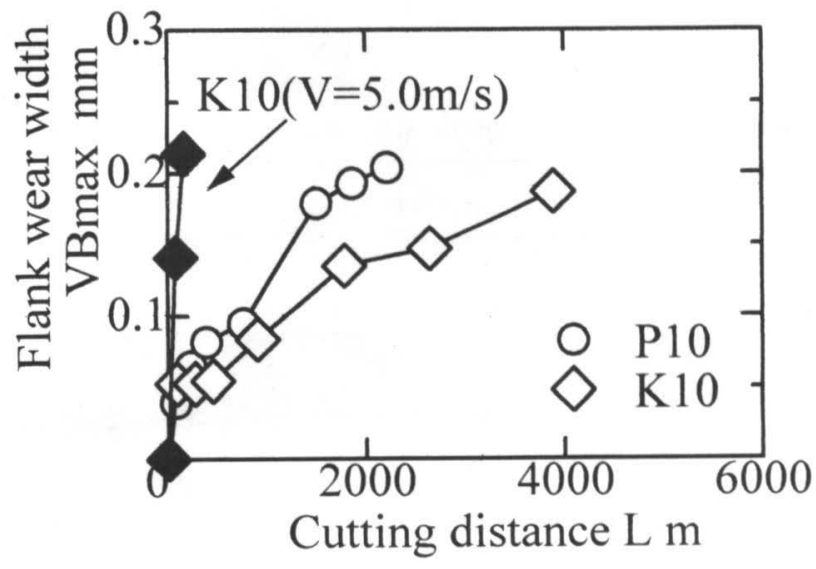

Fig.4 Relation between cutting distance and flank wear width.

硬合金 $\mathrm{K} 10$ 種工具の摩耗進行は切削速度の増加につれ急速に なる。

以上のことから，超硬合金 $\mathrm{K} 10$ 種は，高速で工具の摩耗進 行が速くなるが, 超硬合金の中では焼結ステンレス鋼の切削 
に有効な工具材であることがわかった. そこで，これを母材 とした 4 種のコーテッド超硬合金工具 A, B, C, Dについて, 焼 結ステンレス鋼の切削を行い工具摩耗を調ベた. Fig.5に，切 削速度 $5.0 \mathrm{~m} / \mathrm{s}$ の場合の摩耗進行を示す. コーテッド超硬合金 工具 D の摩耗進行は, コーテッド超硬合金工具 B に比べかな り速い.これは, Fig.3(d)に示したようにコーテッド超硬合金 工具 $\mathrm{D}$ のすくい面には, コーティンク層の剥離ならびに凝着 物が見られた.このことからコーテッド超硬合金工具 Dで焼 結ステンレス鋼を切削すると，凝着物が工具に付着しやすく なる.CVD被覆膜は, 一般に高温処理であるため密着性に優 れるが, 母材との熱膨張差に基づく被膜中での残留引張り応 カやクラックの発生により, 強度が著しく低下する問題があ $3^{11)}$. コーテッド超硬合金工具 Dは, この問題に対しかなり 改善されているが, 切削距離 $500 \mathrm{~m}$ 付近で凝着物によりコー ティング層が剥離し工具摩耗が急增した。

以上のことから, 焼結ステンレス鋼の切削には, TiVN 被覆 のPVD コーテッド超硬合金工具が有効であることがわかる. 3.3 セラミックスエ具および CBN 工具

\subsection{1 工具の摩耗状態}

4種のセラミックスエ具ならびに 3 種の CBN 工具で焼結ス テンレス鋼の切削を行い, 工具の摩耗状態を調ベた. 切削速 度 $5.0 \mathrm{~m} / \mathrm{s}$ の場合を, Fig.6に示す. (a)に示すセラミックスエ 具Wの場合, コーナ部の逃げ面に欠損が見られる. (b)に示す $\mathrm{CBN}$ 工具 Cの場合, コーナ部の逃げ面がやや 3 角形状に摩耗 し, しかも刃先が平らに摩耗ている. また, (c)に示すCBN工 具Dの場合, 送り境界部に欠損が生じている.これに対し, (d) に示すCBN工具 Nの場合, 境界摩耗や欠損など特徵のある工 具損傷はみられない. また，すくい面にも大きなクレータは 見られない。

\subsection{2 工具の摩耗進行}

Fig.7に, 切削速度は $5.0 \mathrm{~m} / \mathrm{s}$ における各種セラミックスエ具 の摩耗進行を示す. Fig.5に示したコーテッド超硬合金工具の 場合と比較すると, $\mathrm{Al}_{2} \mathrm{O}_{3}$ セラミックス工具 $\mathrm{W}$ の摩耗進行が かなり速く, また 2 種類の $\mathrm{Al}_{2} \mathrm{O}_{3}-\mathrm{TiC}$ セラミックスエ具 $\mathrm{B}, \mathrm{T}$ の

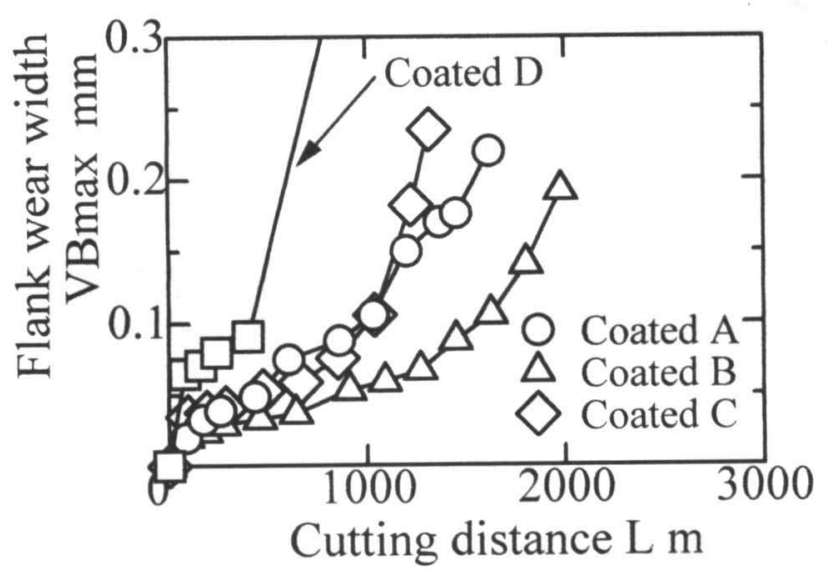

Fig.5 Relation between cutting distance and flank wear width.
摩耗進行も速い.これら 3 種類のセラミックスエ具の摩耗進 行が速くなるのは, 次の理由が考えられる. 先ず, $\mathrm{Al}_{2} \mathrm{O}_{3} セ 5$ ミックスエ具 $\mathrm{W}$ の場合, 凝着物による大きな欠損がみられ た.このため, セラミックスエ具 $\mathrm{W}$ 主な摩耗機構は凝着摩 耗と考えられる.これは, 工具材であるアルミナセラミック スと被削材中の $\mathrm{Ni}$ が反応(主として凝着)しす, 摩耗が大きく
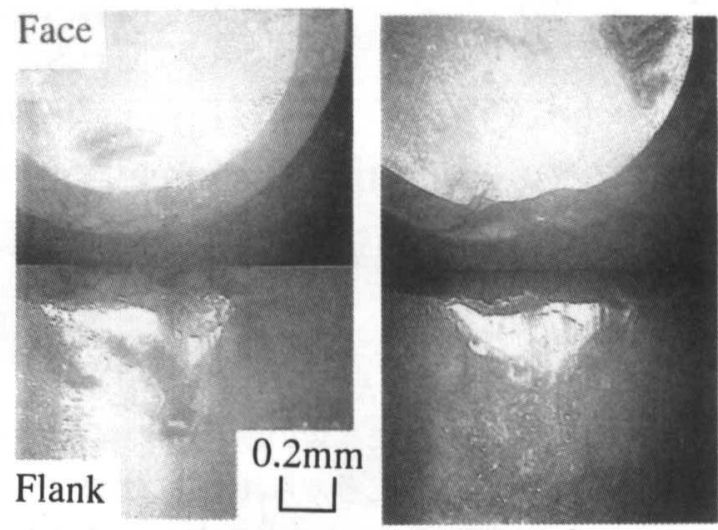

(a) Ceramics W

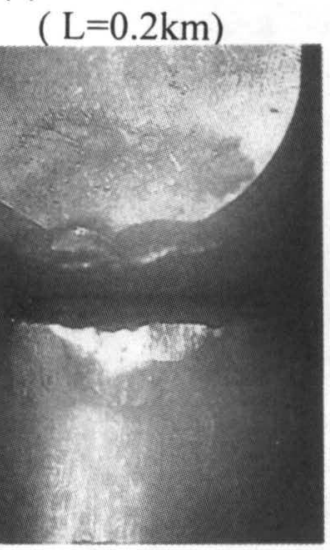

(c) $\mathrm{CBN} D$

( $\mathrm{L}=5.9 \mathrm{~km})$

(b) $\mathrm{CBN} \mathrm{C}$

( $\mathrm{L}=2.5 \mathrm{~km})$

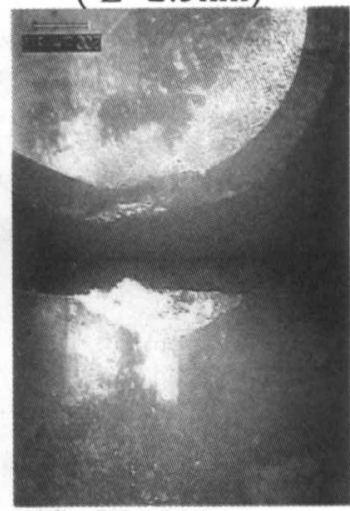

(d) $\mathrm{CBN} \mathrm{N}$

( $\mathrm{L}=5.9 \mathrm{~km}$ )

Fig.6 Tool wear.

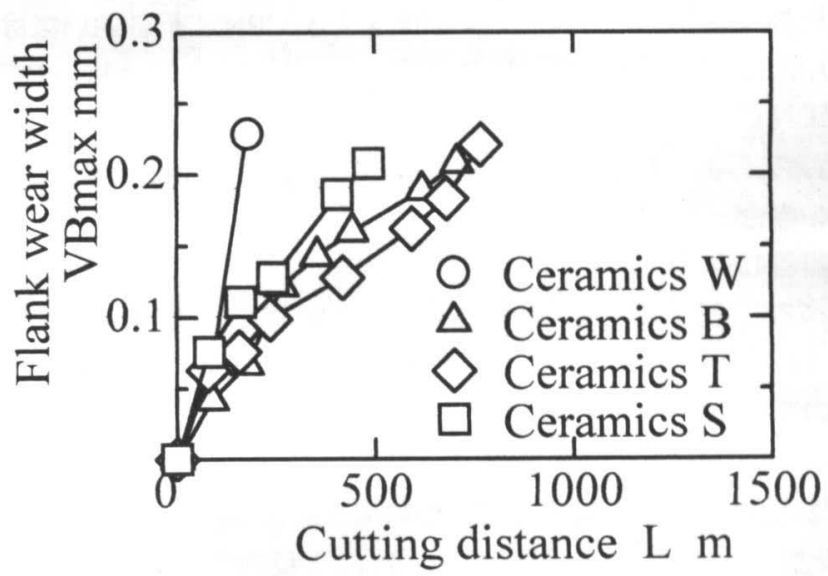

Fig.7 Relation between cutting distance and flank wear width. 


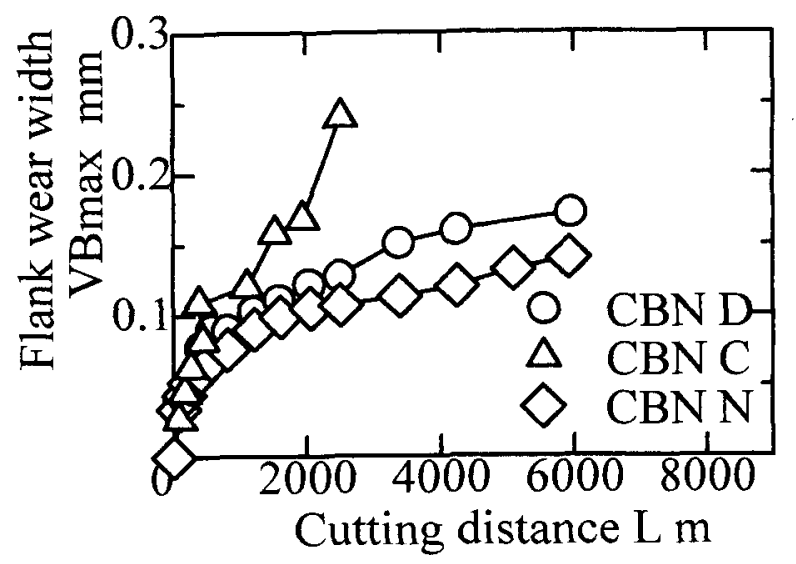

Fig. 8 Relation between cutting distance and flank wear width.

なったと考えられる。次に, $\mathrm{Al}_{2} \mathrm{O}_{3}-\mathrm{TiC}$ セラミックス工具 $\mathrm{B}, \mathrm{T}$ の場合, $\mathrm{Al}_{2} \mathrm{O}_{3}$ セラミックス工具Wの場合と同様, 凝着によっ てある程度の摩耗が生じると考えられる。この場合, $\mathrm{Al}_{2} \mathrm{O}_{3}$ $\mathrm{TiC}$ セラミックス工具 $\mathrm{B}, \mathrm{T}$ の抗折力は，セラミックス工具 $\mathrm{W}$ に比へ大きい ${ }^{12-14)}$ ため，凝着物による工具材の破損の程度は 小さくなると考えられる．しかし，熱伝導率の小さい焼結ス テンレス鋼の切削では，切削温度が高くなると推察される。 耐酸化性や $\mathrm{Fe}$ との耐反応性について $\mathrm{TiC}$ は $\mathrm{Al}_{2} \mathrm{O}_{3}$ より劣る ${ }^{15}$ ことから, $\mathrm{Al}_{2} \mathrm{O}_{3}-\mathrm{TiC}$ セラミックス工具 $\mathrm{B}, \mathrm{T}$ の $\mathrm{TiC}$ が被削材中 の $\mathrm{Fe}$ と反応し，工具摩耗を增大させる. なお，窒化けい素系 セラミックス工具 $\mathrm{S}$ の場合，顕著な切りくずの凝着は見られ なかったが摩耗進行は速い．これは，窒化けい素セラミック スは $\mathrm{Fe}$ との反応性が高い尚ためであると考えられる.

以上のことから，焼結ステンレス鋼の切削においては，い ずれのセラミックスエ具の摩耗進行もPVDコーテッド超硬合 金工具よりも速くなることから，セラミックス工具は焼結ス テンレス鋼の切削に有効でないことがわかる。

Fig.8に，CBN工具の場合を示す．TiN結合材の CBN 工具 N の摩耗進行が最も遅く，焼結ステンレス鋼の切削に有効であ ることがわかる.なお, セラミックスエ具の中では, $\mathrm{Al}_{2} \mathrm{O}_{3}$ セ ラミックス工具 $\mathrm{W}$ の摩耗進行は, $\mathrm{Al}_{2} \mathrm{O}_{3}-\mathrm{TiC}$ セラミックスエ 具 $\mathrm{B}, \mathrm{T}$ に比へ速かった。これに対し，CBN工具においては， $\mathrm{Al}_{2} \mathrm{O}_{3}$ 結合材の CBN 工具 D 摩耗進行は， TiC 結合材の CBN 工具Cに比べ遅い。これには，次の理由が考えられる。すな わち, $\mathrm{Al}_{2} \mathrm{O}_{3}$ 結合材の $\mathrm{CBN}$ 工具 $\mathrm{D}$ の場合，セラミックス工具 の場合と同様, $\mathrm{CBN} 工$ 具 $\mathrm{D}$ の結合材 $\mathrm{Al}_{2} \mathrm{O}_{3}$ と被削材中の $\mathrm{Ni}$ 占 凝着しやすいと考えられる。しかし，セラミックス工具と比 べるとCBN工具は一般的に耐欠損性が高いわことから，CBN 工具Dでは凝着による工具材の破損の程度が小さくなり工具 の摩耗進行が遅くなったと考えられる.これに対し，TiC結合 材のCBN工具Cの摩耗進行が速くなるのは，上述のように耐 酸化性や $\mathrm{Fe}$ との耐反応性について $\mathrm{TiC}$ は $\mathrm{Al}_{2} \mathrm{O}_{3}$ より劣る ${ }^{19} こ$ とから，結合材 $\mathrm{TiC}$ が被削材中の Fe と反応するためと考えら れる。

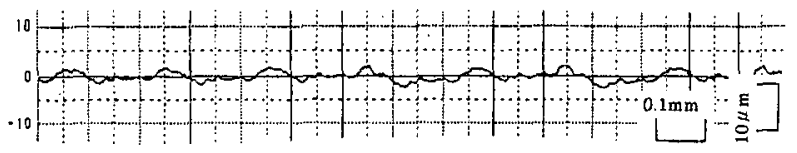

(a) $\mathrm{CBNC}(\mathrm{L}=1.0 \mathrm{~km}, \mathrm{Ra}=0.76 \mu \mathrm{m})$

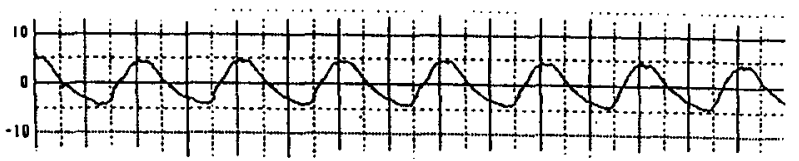

(b) CBN D ( $\mathrm{L}=5.9 \mathrm{~km}, \mathrm{Ra}=2.7 \mu \mathrm{m})$

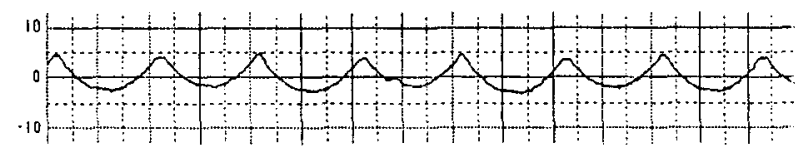

(c) CBN N ( L $=5.9 \mathrm{~km}, \mathrm{Ra}=1.8 \mathrm{~m} \mu \mathrm{m})$

$V=5 \mathrm{~m} / \mathrm{s}, S=0.2 \mathrm{~mm} / \mathrm{rev}, a=0.1 \mathrm{~mm}$, Sintered stainless steel

Fig.9 Surface profile curves.

\subsubsection{CBN 工具の切削仕上げ面}

CBN工具で焼結ステンレス鋼を切削した場合の送り方向の 仕上げ面のプロファイルを調ベた. Fig.9に，切削速度 $5.0 \mathrm{~m} / \mathrm{s}$ の場合を示す．なお，図中の断面曲線より下側か，被削材焼 結ステンレス鋼である. (b), (c)にそれぞれ示すCBN工具 D, N の場合，送り $0.2 \mathrm{~mm}$ をピッチとする送りマークが見られる. これに対し，(a)に示すCBN工具Cの場合，送りマークは，か なり不規則な形状となっている。.また，CBN工具Dの場合， 送り境界部にやや大きな境界摩耗が生じたため, CBN 工具 N の場合に比へ，仕上げ面は粗くなっている．

以上のことから，TiN結合材の CBN 工具Nは，耐摩耗性に 優れ，また良好な仕上げ面も得られることがわかる。

\section{4 結 言}

本研究では，焼結ステンレス鋼を各種工具で旋削し，主と して工具摩耗を調へた。

得られた主な結果は，次の通りである。

（1）超硬合金工具の中では, 超硬合金K10種工具が, 焼結ステ ンレス鋼の切削に適した工具である.しかし，切削速度を 大きくすると超硬合金 $\mathrm{K} 10$ 種工具の摩耗進行は急速にな る.

（2）超硬合金 K10 種工具を母材とするコーテッド超硬合金工 具で焼結ステンレス鋼を切削すると, TiVN被覆PVDコー テッド超硬合金工具の摩耗進行は最も遅い。これに対し， CVD コーテッド超硬合金工具の摩耗進行は急速になり， 凝着によるコーティング層の剥離が発生する。

(3) いずれのセラミックスエ具の摩耗進行は急速になり,アル ミナセラミックス工具には凝着による欠損が兒られる。

(4) 本研究で使用した工具の中では, TiN 結合材の CBN 工具 の摩耗進行が最も遅く, しかも良好な仕上げ面が得られ る. 
謝辞

CBN工具を提供していただきました東芝タンガロイ株式会 社，ならびに被削材焼結ステンレス鋼を提供していただきま した三菱マテリアル株式会社に深く感謝の意を表します.

\section{文献}

1)（社)精密工学会: " 新版 精密工作便覧", コロナ社, 東京, (1992)814.

2)（社) 精密工学会: " 新版 精密工作便覧 ", コロナ社, 東京, (1992) 139 .

3）鳴瀧則彦，村越昭男："焼結鋼の被削性 ", 精密機械, 47(1981)1516-1522.

4) S.Hanasaki, J.Fujiwara and T.Wada: "TOOL WEAR IN HIGH SPEED TIURNING OF SINTERED STEELS", Proceedings of the International Conference on Precision Engineering, Y.Lian and N.Ueda ed., Taipei, Japan Society for Precision Engineering, (1997)351-356.

5）鳴瀧則彦: " 高速切削におけるセラミック系工具の損傷", 日本機械学会論文集 (C偏), 58(1992)675-683.

6) 新谷一博, 加藤秀治, 前田隆夫, 藤村善雄, 山本明: "イン コネル 718材加工における CBN工具の摩耗特性", 精密工
学会誌 , 58(1992)1685-1690.

7) 新谷一博, 加藤秀治, 藤村善雄, 山本明: "CBN工具による オーステンパ処理を施したベイナイト球状黒鉛鋳鉄の切 削特性 ", 精密工学会誌, 56(1990)2261-2266.

8) 加藤秀治, 新谷一博, 藤村善雄: "ADI材加工における CBN 工具の摩耗特性 ", 日本機械学会論文集 (C 編 ), 57(1991) 3027-3031.

9) 中山一雄: " 切削加工論 ", コロナ社, 東京, (1978)188.

10) 東芝タンガロイ : "98 東芝タンガロイ切削工具 ", (1998) 623.

11）小林正樹：" 硬質膜の加工工具への応用 ", 精密工学会誌, 59 (1993)377-380.

12) 日本タングステン: "セラミックス切削工具 (KC5050)".

13) 東芝タンガロイ: "93東芝タンガロイ切削工具", (1993)597.

14) 尾頭勇, 鈴木淳一郎: "ダクタイル鋳鉄切削用セラミック ス工具 HC6", 機械と工具, 9(1988)48-51.

15）鈴木寿: " 超硬合金と焼結硬質材料一基礎と応用一", 丸 善, 東京, (1986)228.

16) 林桂: "セラミックエ具",精密工学会誌, 61(1995)764-768.

17) (社) 精密工学会: " 新版 精密工作便覧 ", コロナ社, 東京, (1992)76. 